\title{
E-MASTER IMPLEMENTATION IN THE EFFORTS TO SUPPORT THE PERFORMANCE OF PUBLIC SERVICES IN THE REGIONAL CIVIL SERVICE AGENCY OF EAST JAVA PROVINCE, INDONESIA
}

\author{
Puspasari Yenni Dwi \\ Master Program of Human Resource Development, University of Airlangga, Indonesia \\ E-mail: yennidwipuspasari@gmail.com
}

\begin{abstract}
Purpose of this study is to realize the principles of good governance, improving the quality of staffing services to the community, increasing the satisfaction of staffing services for the community and increasing transparency and accountability of staffing services. In general, with the innovation of public services called E-master this is very good and helps staffing services at the Regional Civil Service Agency of East Java Province, but the obstacle faced is the problem of Human Resources Apparatus that is less competent so that the staffing services are somewhat less than optimal. The type of research used is descriptive qualitative. Data collection techniques were obtained by interviewing techniques directly to several informants, conducting observations where the researcher recorded the information witnessed during the research as a supplement to the research material and with the documentation method looking for personnel data and the organizational structure of the Regional Personnel Board of East Java Province. From the results of this study, it can be concluded that the Human Resources Apparatus is very influential on the performance of staffing services and service quality at the Regional Civil Service Agency of East Java Province.
\end{abstract}

\section{KEY WORDS}

E-government, public service, service, quality, performance, human resources apparatus.

Bureaucracy in Indonesia has a function not only in the management of the government but also in the service of the community. Therefore, the most expected by the Government is that the State Civil Service works competitively and the most important is the loyalty of the Apparatus in serving the community optimally in accordance with the Main Duty and Function in order to provide the best service to the community.

Several studies in various developing countries show that Governments in developing countries including Indonesia do not carry out government online at all because the government in the country is still traditional and there are no experts who are competent to implement electronic Government (e-government). The most important element in implementing e-government is human resources and adequate facilities, requiring competent and qualified experts.

Public services are carried out by the government to people who request services. The government is obliged to serve the community with services that provide convenience without complicating the procedure.

E-master is an application for personnel services in the management of integrated and integrated State Civil Apparatus in the East Java Provincial Government. The application of e-master is a service system created for personnel affairs in the East Java Provincial Government. Until before the e-master existed, the implementation of the SOP (Service Operational Standards) and the SPP (Standard Procedure Service) of staffing had not been implemented consistently and committed, so service time was generally inefficient which could harm service users. In addition, the utilization of information and communication technology is still not optimized, so that complaints about employment services are not well accommodated and not yet one door.

Constraints that occur in the field are at each individual State Civil Apparatus, the ineffectiveness of services to achieve the target of collecting data every year is caused 
because the file in question is missing, for example, such as Birth Certificate, Education Diploma, Employee Card, and so forth. In addition, the service barriers at the East Java Provincial Personnel Agency are also caused by stalled services, for example, the creation of an Electronic Employee Card, which was then issued by the State Civil Service Agency. So that the East Java Provincial Personnel Agency decreases staffing service standards by replacing the requirements of Electronic Employee Cards using a valid and updated statement letter with a Decree. The East Java Provincial Personnel Agency only has one employee as the server of the E-Master, so that various obstacles that arise regarding staffing data that has been uploaded by employees cannot be maximized to be completed simultaneously, this is the service obstacle that occurs in the Civil Service Agency Region of East Java Province. Human Resource Development efforts to play an important role, namely server E-Master has been conducted by team, the assessment but so far no one who meets the criteria. In addition, the Regional Civil Service Agency of East Java Province, especially the admin, also provided socialization to system administrators and field operators. But an innovation in the form of a system for the service of the State Civil Apparatus is not as easy as providing socialization, the obstacle faced by the Regional Civil Service Agency of East Java Province is after the socialization takes place, then the hopes are hastened to fulfill the personal data, especially the State Civil Apparatus, but the realization is not expected even slow, some are filling with perfunctory and incomplete. The author also observed that in several instances there were State Civil Apparatus who did not yet understand and know about the e-master program, because the Regional Devices Organization operators sometimes did not want to give socialization to the State Civil Apparatus in the agency, especially in the State Civil Apparatus which was classified as old and less productive, so that inevitably the operator of the Regional Devices Organization that complements the data with data that has been provided by the previous State Civil Apparatus. Not all State Civil Apparatus understand about Information Technology (IT) and also Civil Apparatus in the pension state tend to have low participation rates.

The purpose of this study was to find out how the application of the E-Master in an effort to support the performance of public service delivery, to find out any obstacles in the implementation of the E-Master in an effort to support the performance of public service delivery and to determine the impact of implementing E-Masters in supporting implementation performance public services at the Regional Civil Service Agency of East Java Province.

\section{LITERATURE REVIEW}

Bernardin and Russel (1993: 378) provide an understanding of performance as follows: "performance is defined as the record of outcomes produced on a specified job function or activity during the time period.". Achievement or performance is a record of the results obtained from certain job functions or activities during a certain period of time.

According to Davidow and Uttal in Surjadi (2012: 57), that service is any business that enhances customer satisfaction. According to Sinambela (2014: 5), public service is the fulfillment of the wishes and needs of the community by state administrators.

Zeithaml in Hardiyansyah (2011: 41) explains that the measure of service quality has five SERVQUAL dimensions (service quality) and each indicator as follows:

Tangible Dimension, consisting of indicators:

- The appearance of officers/apparatus in serving customers;

- Comfort of service;

- Disciplinary officer/personnel in the services;

- Ease of processes and access to services;

- Of use tools in the service.

Reliability Dimension, made up of indicators:

- Accuracy officers in serving customers;

- Have service standards that clearly; 
- Ability officers/personnel in using the tools in the service process;

- Expertise officer in using the tools in the service process.

Responsiveness Dimension, made up of indicators:

- Responding to each customer/applicant who wants to get service;

- Officer/personnel perform fast and accurate service;

- Officer/officers in the service of carefully;

- All complaint the customer needs to be responded by the officer. Assurance Dimension (Guarantee), consisting of indicators:

- Officers guarantee timely service;

- Officers guarantee legality in the service;

- Provider guarantees certainty of costs in service. Empathy Dimension, consisting of indicators:

- Lower the interests of the applicant/customer;

- Officers serve with a friendly attitude;

- Officers serve with a courtesy attitude;

- Officers serve and respect each customer.

\section{METHODS OF RESEARCH}

Type of research used in this study is to use a descriptive research method with a qualitative approach. The research subjects in this study were the Head of Planning, Procurement, Data Processing and Information Systems, and the operator of the Electronic Integrated Civil Servants Program (E-master) and E-Master Program developer. This study took place in the Regional Personnel Agency of East Java Province. Data collection techniques were obtained by interviewing techniques directly to several informants, conducting observations where the researcher recorded the information witnessed during the research as a supplement to the research material and with the documentation method looking for personnel data and the organizational structure of the Regional Personnel Board of East Java Province. The source of this research data is person, place, and paper. The data analysis technique used in this study is interactive analysis (Interactive Model of Analysis). In this analysis, the researcher moves in three components of analysis, namely, data reduction, presentation of data, concluding drawings during the research.

\section{RESULTS AND DISCUSSION}

Quality of service in the East Java Provincial Civil Service Agency uses service quality indicators delivered by Zeithaml, Berry, and Parasuraman (1990). The quality of service in the Regional Civil Service Agency of East Java Province can be seen in this table:

Table 1 - Quality of Service in the East Java Provincial Civil Service Agency E-Master-based Personnel Service

\begin{tabular}{|l|l|l|}
\hline No. & Indicator & Explanation \\
\hline 1. & Tangibles & $\begin{array}{l}\text { Physical facilities at the Regional Civil Service Agency of East Java Province is } \\
\text { inadequate. Personnel Services E-Master-based are services carried out online. } \\
\text { Whereas server needs and lack of network capacity. However, computer facilities and } \\
\text { laptops as mediators based staffing services E-Master-are sufficient and adequate. }\end{array}$ \\
\hline 2. & Reliability & $\begin{array}{l}\text { In this case the ability of the Regional Civil Service Agency of East Java Province as a } \\
\text { service provider has been good but has not been fully realized in accordance with } \\
\text { existing procedures. The determination of time in each staffing service is appropriate } \\
\text { and timely in accordance with the Standard Operating Procedure for Civil Service } \\
\text { Services at the Regional Personnel Agency of East Java Province. }\end{array}$ \\
\hline 3. & Responsiveness & $\begin{array}{l}\text { Desire of the staff to assist the state civil apparatus is felt to be very good. Evidenced by } \\
\text { the number of state civil apparatus who are satisfied with the response given by staffing } \\
\text { service providers and at least complaints about services sent to the online greeting web } \\
\text { (the web owned by the East Java Provincial Civil Service Agency which contains input, } \\
\text { complaints and sharing about staffing). }\end{array}$ \\
\hline
\end{tabular}




\begin{tabular}{|l|l|l|}
\hline \multicolumn{2}{|l|}{ Table 1 Continue } & \multicolumn{2}{l|}{$\begin{array}{l}\text { The ability of service providers to give assurances of confidence in the civilian apparatus } \\
\text { of the state employment service that's good enough. Service providers provide } \\
\text { guarantees in accordance with existing procedures. }\end{array}$} \\
\hline 5. & Assurance & $\begin{array}{l}\text { The ability of service providers to provide services and attention to users of personnel } \\
\text { services individually is quite good. Frequently conduct two-way communication, namely } \\
\text { towards staffing services in each agency in the East Java Provincial Government } \\
\text { environment related to the completeness of staffing staff data, the State Civil Apparatus } \\
\text { as a user of personnel services which is a barrier to achieving service targets because } \\
\text { the Apparatus Human Resources are not all adequate. }\end{array}$ \\
\hline
\end{tabular}

Source: The results processed from interview data.

Of the above research suggest that the State Civil Apparatus as service users wants every staffing service to be completed in accordance with the standards of staffing service time. But the reality that happens is not the service at the Civil Service Agency that is the source of the existing problems, but the user of personnel services, namely the State Civil Apparatus in every Institution in the Government of East Java Province. But the East Java Provincial Personnel Agency has so far never experienced delays in personnel affairs because of the two-way communication carried out to personnel managers in each agency in order to prepare the file as soon as possible before the maturity of the personnel file management. Physical facilities which are also factors that influence the quality of service are gradually addressed, namely by proposing Budget planning in the following year.

Since the establishment of Service Procedure Operational Standards in the Regional Civil Service Agency of East Java Province, the level of implementation of staffing services has increased significantly, physical and Human Resources services are quite representative so that service targets can increase each year.

The East Java Provincial Civil Service Agency has a website facility www.bkd.jatimprov.go.id in which there is a complaint service called Sapaan Online. This facility as well as sharing staffing problems can also be used as a complaint.

\section{CONCLUSION AND SUGGESTIONS}

From the results of the research and discussion above, researchers can give conclusions in accordance with the formulation of the problem is basically the first element that affects the quality of service is the Human Resources Apparatus, because not all apparatuses are able to use information technology so that delays and incompleteness of files and the data that will be used as management of personnel affairs becomes constrained, so that not only the staffing matters are a problem, but the service to the Regional Civil Service Agency of East Java Province is also hampered and in the end some staffing arrangements are completed more than the time stipulations stated in the Operational Standards Existing service procedures. The lack of socialization about E-Master as the supporting mediator of staffing services and the importance of updating the data on the E-Master to support staffing data so that it simplifies personnel affairs.

Physical facilities in the form of servers are important in the management of E-Master based (staffing services online), the limited server owned by the Regional Civil Service Agency of East Java Province is an obstacle in managing personnel services because with the many State Civil Apparatus in the East Java Provincial Government the greater the capacity of E-Master service users to access it. In this case server facilities must be balanced with the number of State Civil Apparatus in the East Java Provincial Government.

From the conclusions, the researcher draws advice, namely with the presence of Apparatus Human Resources who are less active in staffing based on E-Master (online), the East Java Provincial Civil Service Agency needs to socialize to the East Java Provincial Government Agencies about the important role of updates, file individual staffing and strategic forms of E-Master based (staffing services online). Personnel managers can also take part in dealing with apparatus that are less capable of Information Technology facilities such as guiding and teaching them. With the existence of new public service innovations in 
the form of E-Masters in the Regional Civil Service Agency of East Java Province, it can propose budget planning in the following year for the addition of servers or other staffing support facilities. Thus the performance of E-Master-based staffing services at the East Java Provincial Civil Service Agency is good, but it must be improved better so that all matters of staffing services can run smoothly, efficiently and on time.

\section{REFERENCES}

1. Bernardin and Russel. 1993. Human Resource Management. New Jersey: International Editions Upper Saddle River, Prentice Hall.

2. Hardiansyah. 2011. Kualitas Pelayanan Publik. Yogyakarta: Gava Media.

3. Sinambela, Litjan Poltak, dkk. 2014. Reformasi Pelayanan Publik. Jakarta: PT.Bumi Aksara.

4. Surjadi. 2012. Pengembangan Kinerja Pelayanan Publik. Bandung: Refika Aditama.

5. Zeithmal, Valarie A, A.Parasuraman \& Leonard L. Berry. 1990. Dilevery Quality Sevice. New York: The Free Press. 